\title{
Analysis of CSR Legislation in Indonesia: Mandate to Business
}

\author{
Rabin Ibnu Zainal \\ Universitas Bina Darma, Jl. A. Yani No.3, Palembang, Indonesia \\ Tel: 62-811-718-481Ｅ-mail: rabin.zainal@binadarma.ac.id
}

Received: June 28, 2019 Accepted: July 16, 2019 Published: August 16, 2019

doi:10.5296/ber.v9i3.14978ＵRL: https://doi.org/10.5296/ber.v9i3.14978

\begin{abstract}
Indonesia was one of the first countries in the world to implement legislation mandating businesses to undertake Corporate Social Responsibility (CSR). Different with other countries with their voluntary approach of CSR, the legislation makes CSR as a mandate to business in Indonesia. Through document analysis method, this study analyses six laws related to CSR in Indonesia to define the mandate of CSR legislation in order to understand the form of CSR should be practiced by companies operating in Indonesia. Indonesia as one of the developing countries may require sufficient fund for their local development. CSR may be seen as a source of fund for local development. Therefore, CSR legislation in the country provides mechanism for wealth or resource distribution of companies for local government to develop local communities.
\end{abstract}

Keywords: Corporate social responsibility, Laws, Mandate, Business, Indonesia

\section{Background}

The involvement of business in the local development of Indonesia is recognized through Corporate Social Responsibility (CSR) projects. The demand of company contributions on local development increase after decentralization was implemented in the country since 2000. Such demands have also forced the central government to mandate CSR legislation, requiring business, particularly those related to natural resources, to undertake CSR.

The two CSR related laws which were enacted during this decentralization era are the Investment law No. 25/ 2007 and Limited Liability Companies (LLCs) Law No 40/ 2007. These laws are acknowledged as amongst the world's first laws for mandatory CSR (Rosser \& Edwin, 2010; Waagstein, 2011). Further, other laws and government regulations were followed these two laws in mandating business to conduct CSR. The laws issued by central government considering the local government requests on the obligation of companies 
operating in their areas to actively give contribution on the local development. Local development in some areas in Indonesia were also issued local regulation to ensure businesses in their areas to undertake obligation on CSR as mandated by the central government laws (Zainal, 2006).

These enacted laws have made CSR mandatory in Indonesia, creating a different situation from that of CSR practices in developed countries. Regarding the latter, according to Carroll (Carroll, 1991), CSR extends business practices beyond their required economic and legal responsibilities to accepting ethical, moral, and discretionary responsibilities, in order to improve society. This social responsibility should not, however, interrupt the main responsibility of businesses to provide economic goods and services to community, and their responsibility to provide profits to shareholders. Within the frame of these assumptions, CSR is based on voluntariness on the part of companies in their initiatives (Carroll, 1991, 1999). The presence of mandated CSR legislation in Indonesia, by contrast, impels company compliance to the legislation regardless of any interruption to their economic responsibilities.

The motivation underpinning this study is the need to explore what are the mandates of CSR legislation to business in Indonesia. By knowing the mandates of CSR legislation, the research would assist the business to build their CSR strategy in Indonesia. The legislation is no doubt created an opportunity for local governments and local communities to demand business CSR. A decentralization process transferred much of central government authority to kota (municipality) and kabupaten (district) levels of government provide challenge to business to settle their operations in the municipalities and districts that are rich of natural resources and predominantly located outside of Java.

\section{Research Question and Objective}

The main key research question framed for this study is: "What are the main mandates of CSR legislation for business operating in Indonesia?" The research has objective to qualitatively examine the CSR legislation in Indonesia.

As we described earlier, the Indonesian government has taken a different stance from most other countries by introducing mandatory legal requirements for CSR through legislation (Waagstein, 2011). Thus, Indonesia provides a unique context for researching CSR. This legislation allows government intervention in company CSR decisions, a situation differing from that mostly found in the CSR literature, which assumes voluntariness and self-determining policies in company CSR decisions (Carroll, 1991). Moreover, Donaldson and Dunfee (Donaldson \& Dunfee, 1999) argue that CSR should be seen as an implicit claim by local stakeholders because, unlike consumers, suppliers or shareholders, local stakeholders do not have any explicit contract agreement with companies. However, the issuance of CSR laws in Indonesia changes the status of their claim, explicitly granting local stakeholder demands for company CSR contributions. Therefore, the research aim to examine the mandate of CSR legislation as the laws representing the stakeholder demand to business CSR. 


\section{Literature Review}

This section explores the extant literature on Corporate Social Responsibility (CSR), particularly on the three domains of CSR, CSR in the developing countries context and types of CSR regulations.

\subsection{Three-Domains of CSR}

There is no single universal shared definition of Corporate Social Responsibility (CSR), with many scholars pointing to the lack of an agreed definition as a potential weakness within the literature of the CSR field (Van Marrewijk, 2003; Windsor, 2006). The earliest definition of CSR proposed by Bowen (1953, quoted in Carroll 1999, p.25) referred to 'social responsibility' as the obligations of businessmen to pursue those policies, to make those decisions, or to follow those lines of action which are desirable in terms of the objectives and values of our society. This definition introduced a normative value through the acknowledgement that society should be considered as an important component in the decision making process of businesses.

CSR definitions recently are grounded solely in the perspective of the company as the main actor that voluntarily initiates to undertake CSR. The definitions developed by scholars can be divided into two perspectives. The narrow perspective allows companies to include their economic interests such as value maximization or competitive advantage as a basis to undertake CSR voluntarily (Carroll, 1999; Friedman, 2007). In the broad perspective of CSR, the inclusion of social goals in company CSR is mainly related to the assumption that those social problems will affect their economic goals, such as the poverty that may impact on their production demand (Schwartz \& Saiia, 2012).

In relation to these definitions, Schwartz and Carroll's (Schwartz \& Carroll, 2003) model of CSR proposed three domains of influence on companies decision to voluntarily implement CSR. These are: (1) economic, (2) legal, (3) ethical. This model was developed from Carroll's (Carroll, 1991) pyramid of CSR; however, Schwartz and Carroll (2003) removed the philanthropic domain from their model, since in reality business philanthropic activities such as giving to charity could be considered driven by either an ethical or an economic motive.

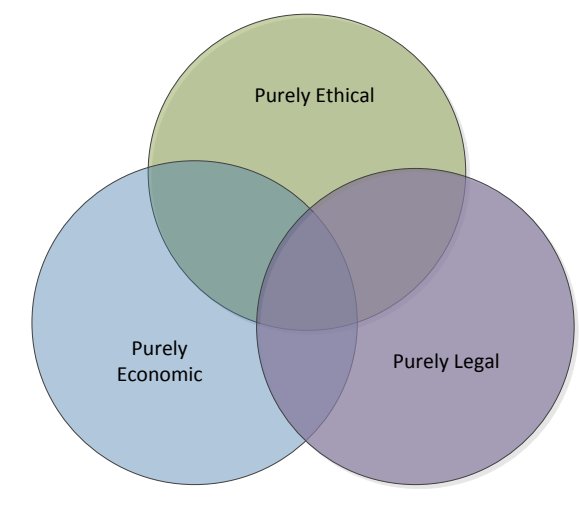

Figure 1. Three Domain Approach of CSR

Source: Adopted from (Schwartz \& Carroll 2003, p. 509) 
In relation to Figure 1, the economic domain generally relates the company's CSR to company performance or profit. This views CSR exclusively as an instrument for the company to achieve its financial objective, which is profit. This domain is also described as the narrow CSR perspective, where businesses will only involve themselves in CSR related activities when there is a clear link to financial performance and CSR is part of the instrument to achieve this economic objective (Friedman, 2007; Maas \& Liket, 2011). Further, Friedman (2007) asserts that if the CSR activities of companies produce a loss or decline in profits this indicates that the activity represents a flawed business decision, because the responsibility of the firm is to achieve profit only, while responsibility for social issues is not an interest of corporations except where it contributes to their economic performance. Berger et.al (2007) affirmed this domain of CSR as the business-case model, mentioning that CSR initiatives from companies are basically assessed in a purely economic manner to pursue a clear link to financial performance. The ethical domain, on the other hand, refers to company activities that fit with the expectations of the community and other relevant stakeholders both domestically and globally. However, it is considered impossible to integrate all stakeholders' expectations as the types of norms in society are varied and depend on context. The Legal domain explains the intention of companies to undertake CSR so as to obey or comply with the law. The law represents a 'codified ethics', which means it is a means of fairness established by the lawmakers through consideration of various norms in the society (Schwartz \& Carroll 2003).

Utilizing the three domains of CSR to describe CSR practices in Indonesia may assist to identify the internal motivation of each company in undertaking CSR, given the CSR legislation in Indonesia. With the existence of CSR legislation it may be assumed that CSR is solely motivated by the company compliance with the legislation. However, it should be questioned if, whether and why then each company practices CSR differently, in implementing the same legislation.

\subsection{CSR in Developing Countries Context}

The practice of CSR in the country is influenced by its institutional environment context. Most of CSR concepts are developed in the context of developed countries where the government intervention is limited to the market. CSR in the developing countries aims to assist governments to achieve their development goals (Ali, Frynas, \& Mahmood, 2017; Desta, 2010). However, governments in developing countries may have limited freedom to intervene in the affairs of companies, particularly Multi-National Companies (MNC), to involve them in development issues. Their need for foreign direct investment (FDI) to create jobs and generate income puts the government in developing countries in a weak negotiating position (Idemudia, 2011). In addition, dependence upon loans from institutions such as the World Bank or IMF (International Monetary Fund), which come attached with loan condition requirements for developing countries to prioritize industrialization, leads governments of developing countries to focus more on protecting company interests, rather than on the welfare of their communities (Dobers \& Halme, 2009). Meanwhile, inside the government, bribery and corruption practices in developing countries mean the authorities tend to prioritize investor interests because they hold the economic influence necessary to their 
corrupt behavior (Adeyeye, 2012).

Market conditions in developing countries often differ considerably from developed countries, in terms of political, macro-economic, cultural or natural conditions. The business environment of developing countries can be characterized as often rather unstable and less predictable than in developed markets, raising the level of uncertainty for companies (Heidenreich \& Puck, 2012). The success of companies is not shaped solely by market actors such as managers, shareholders, customers and suppliers, but also depends on a company's relationship with stakeholders that have political power (Hillman \& Wan, 2005). Without links to governments' officials, non-governmental organizations and other relevant groups, companies can face major business problems in terms of their local permits and local legitimacy.

In relation to CSR in developing countries, the blurred distinction between market and state forces in this environment creates the integration of company roles in politics and the market. The idea of business responsibility mainly as the dominant engine of economic growth and creator of economic value of the developing countries' resources is thus not sufficient (Jamali \& Mirshak, 2007). The kind of institutional environment in most developing countries, such as Indonesia, results in companies being expected to fulfill social obligations in such countries (Idemudia, 2008). Thus, a more crucial agenda of CSR programs in developing countries is their contribution to development-related issues such as reducing poverty and building human capital (Blowfield \& Frynas, 2005). This role has traditionally been regarded as a governmental activity (Brammer, Jackson, \& Matten, 2012), and thus causes companies to act in a state-like role (Matten, Crane, \& Chapple, 2003).

\subsection{Types of CSR Regulation}

The importance of companies' contribution to development has raised the level of government intervention in CSR. In this manner, some governments have formed certain CSR regulations to govern CSR in their countries. The type of CSR regulation made by a government reflects their country's institutional environment, reflecting the relationship between businesses, government and society. Some governments govern CSR only in the form of informal and reflexive laws which basically rely on normative ethical ideas and behavior on the part of companies (Buhmann, 2006). These soft law interventions typically encourage business to adopt CSR standards such as anti-bribery practices (A. Adeyeye, 2011), or build sustainable reporting of CSR activity as part of business requirements (Delbard, 2008).

However, the idea of government intervention is built upon the reciprocal relationship between government and companies. These governments depend on companies and markets for the efficient provision of goods and services that enhance social well-being and in return markets depend on government rules and infrastructure to function efficiently and fairly. Thus, government intervention in CSR should achieve an optimal balance between state intervention and market freedom. Consideration of the government-business relationship has resulted in two key ideas being posited: 'the civic governance' concept whereby the state is required to intervene to protect public good; and the opposite thinking, on 'consumer 
sovereignty' following laissez faire market dynamics with minimum government intervention (Gjølberg, 2011). The ideas of these two schools of thought lead us to ask whether companies' CSR performance is best achieved by "hard law" through legislated regulatory intervention or through "soft law" by delegated voluntary approaches that leverage the power of the market to move companies to be socially responsible.

Table 1. "Hard law" versus "Soft law" regulatory approaches

\begin{tabular}{|l|l|l|}
\hline Type of Intervention & Hard law (prescriptive) & Soft law (voluntary) \\
\hline Setting standards & $\begin{array}{l}\text { Regulatory prescription- traditional } \\
\text { command and control regulation in } \\
\text { which legally binding standards are } \\
\text { prescribed }\end{array}$ & $\begin{array}{l}\text { Information-influence constituents through } \\
\text { the transfer of knowledge and the } \\
\text { communication of reasoned argument and } \\
\text { persuasion }\end{array}$ \\
\hline Enforcing standards & $\begin{array}{l}\text { Economic regulatory instruments- } \\
\text { examples include pollution fees, } \\
\text { emission taxes, and tradable permits } \\
\text { to encourage firms to internalize } \\
\text { environmental costs }\end{array}$ & $\begin{array}{l}\text { Voluntary approaches- examples include } \\
\text { industry self-regulation, codes, voluntary } \\
\text { challenges, eco-labels, } \\
\text { co-regulation, covenants, and negotiated } \\
\text { environmental agreements }\end{array}$ \\
\hline
\end{tabular}

Source: (Gjølberg 2011)

Table 1 shows the types of interventions that can be applied by government, consisting of either "setting standards" or "enforcing standards". Prescriptive hard law approaches prescribe regulatory prescription by government legally binding businesses. Enforcing standards can also be created under hard law by introducing taxing, fees, and permits that are authorized by the government. In contrast, soft law voluntary approaches tend to focus on the transfer of knowledge and communication of government and business, so businesses can voluntarily apply particular standards in their CSR. Government intervention with a soft law approach encourages self-regulation of business through giving rewards such eco labelling, charters, covenants and negotiated environmental agreements.

The hard law approach to regulation is generally criticized for being slow and expensive to develop and operate. The argument against hard law government intervention states that it inhibits company innovation and beyond-compliance behaviour. On the other hand, the soft law voluntary approaches such as self-regulation by business are also criticized for being difficult to apply, less rigorous in their performance requirements and the lack of certainty in public accountability (Gjølberg, 2011).

However, in the developing countries' context, promoting a soft law approach that relies on the voluntariness of company self-regulation and policy setting may not be as appropriate. Porter and van der Linde (Porter \& Linde, 1999), for example, disagree with the proposition that government intervention can raise business costs. They found that in the case of environmental regulations, these can trigger innovations that can offset the costs involved in reducing the negative effect of operations on the environment, resulting in efficiencies and making companies more competitive in the global market. It is also evident that mandatory 
initiatives from government can fill the gap due to a lack of companies' voluntary initiatives to be socially responsible. The penalization of companies for not conducting CSR may force them to comply with mandatory requirements and encourage higher levels of compliance.

While the positive potential of enforcement action and penalties have already been noted for mandatory CSR, these same attributes can also create downsides. For example, with regard to regulation, the costs of enforcement are placed on the government; while limited enforcement resources may lead to increased evasive activity. Furthermore, some commentators have noted that monetary penalties may be insufficient to encourage compliance in all cases and may come to be seen as merely another cost associated with doing business (Bakan, 2012). In such instances, even mandatory regulation may be insufficient to regulate corporate behavior. The drawbacks of a mandatory approach are also associated with the methods used, particularly when they emerge from legislative efforts. The time-consuming nature of legislative undertakings may make regulatory solutions less responsive to quickly evolving situations. Furthermore, it has also been observed that legislation tends to be less tailored to industry needs, an issue that may be important where the regulation will apply to corporations in different sectors and of different sizes.

\section{Research Methodology}

The secondary data of the CSR legislative framework in Indonesia was a key part of this research to analyze the content of the CSR laws and to understand the implications of the legislation. There are 6 (six) laws related to CSR and the accompanying 2 (two) government regulations and 4 (four) ministerial decrees collected for this study purpose. All documents used in this study included printed and/or electronic documents; available from newspaper, the official documents, and the official websites.

The analysis method used was document analysis. As a research method, document analysis is particularly applicable to qualitative case studies and intensive studies producing rich descriptions of a single phenomenon, event, organization, or program (Bowen, 2009). Document analysis involves skimming (superficial examination), reading (thorough examination), and interpretation. This process combines elements of content analysis and thematic analysis. Content analysis is the process of organizing information into categories related to the questions of the research (Krippendorff, 2012). Thematic analysis is a tool to find a pattern recognized within the data. The themes emerge from this process and become the categories for analysis (Vaismoradi, Jones, Turunen, \& Snelgrove, 2016).

\section{Analysis}

This section discusses the Indonesia's CSR legislation and the Mandate to Business.

\subsection{Indonesia's CSR Legislation}

Article 33 of the Indonesia basic Constitution, which was amended in 2002, provides a brief justification that all economic sectors aim to create prosperity for the people of Indonesia. In relation to CSR legislation, all CSR legislation passed by central government and their implementation regulations rest on the power of Article 33 to confirm the central government 
authority over natural resources in the natural resource areas. By stating that the benefit of natural resources is for the prosperity of the Indonesian people, this article provides a justification for central government to enact CSR legislation aiming its benefit towards local communities living nearby the mining companies' operations. Figure 2 presents a comprehensive description of all laws, government regulations and ministerial decrees of Indonesia CSR.

The Indonesian CSR legislation begins with Article 33 of Undang-Undang Dasar 1945 (UUD 1945 - Indonesian Constitution) with its statement that the natural resources should provide prosperity to the Indonesian people, which include local communities. From this position, CSR legislation was established. There are four specific CSR laws that have direct relevance to their companies' operations, which are: (i) Law No 40/2007 on Limited Liability Company, obliging companies related to natural resources to undertake CSR; (ii) Law no 25/2007 on Investment, detailing CSR compliance for all investors; (iii) Law No 22/2001 on Oil and Gas, stating that Community Development (CD) is the obligation of Oil and Gas companies to local communities; and (iv) Law No. 19/2003 on State Owned Companies, stating the obligation to deliver Partnership Program and Environmental Building (PPEB) (or in Indonesian, PKBL- Program Kemitraan and Bina Lingkungan) programs for State Owned Companies (SOC). Aside from those laws, two other relevant laws, which are: (v) Law No. 11/2009 on Social Welfare; and (vi) Law No. 13/2011 on Poverty (Government of Republic of Indonesia 2009, 2011).

The present research distinguishes these six laws into two categories. The category of direct laws refers to the laws that have direct influence on companies operations, such as the Oil and Gas Law No. 22/2001, which should be followed by all Oil and Gas companies during their operations, or the Limited Liability Company Law No. 40/2007, which sets rules and requirements for companies registered in Indonesia. The indirect laws, which are Law No. 11/2009 on Social Welfare and Law No. 13/2011 on Poverty, have no direct influence on company operation. Instead, these two laws encourage local governments at district and provincial levels to involve businesses through their CSR efforts to provide social welfare and eradicate poverty. This suggests that these two indirect laws are symbolic to local government to involve in company CSR, but not to business. 


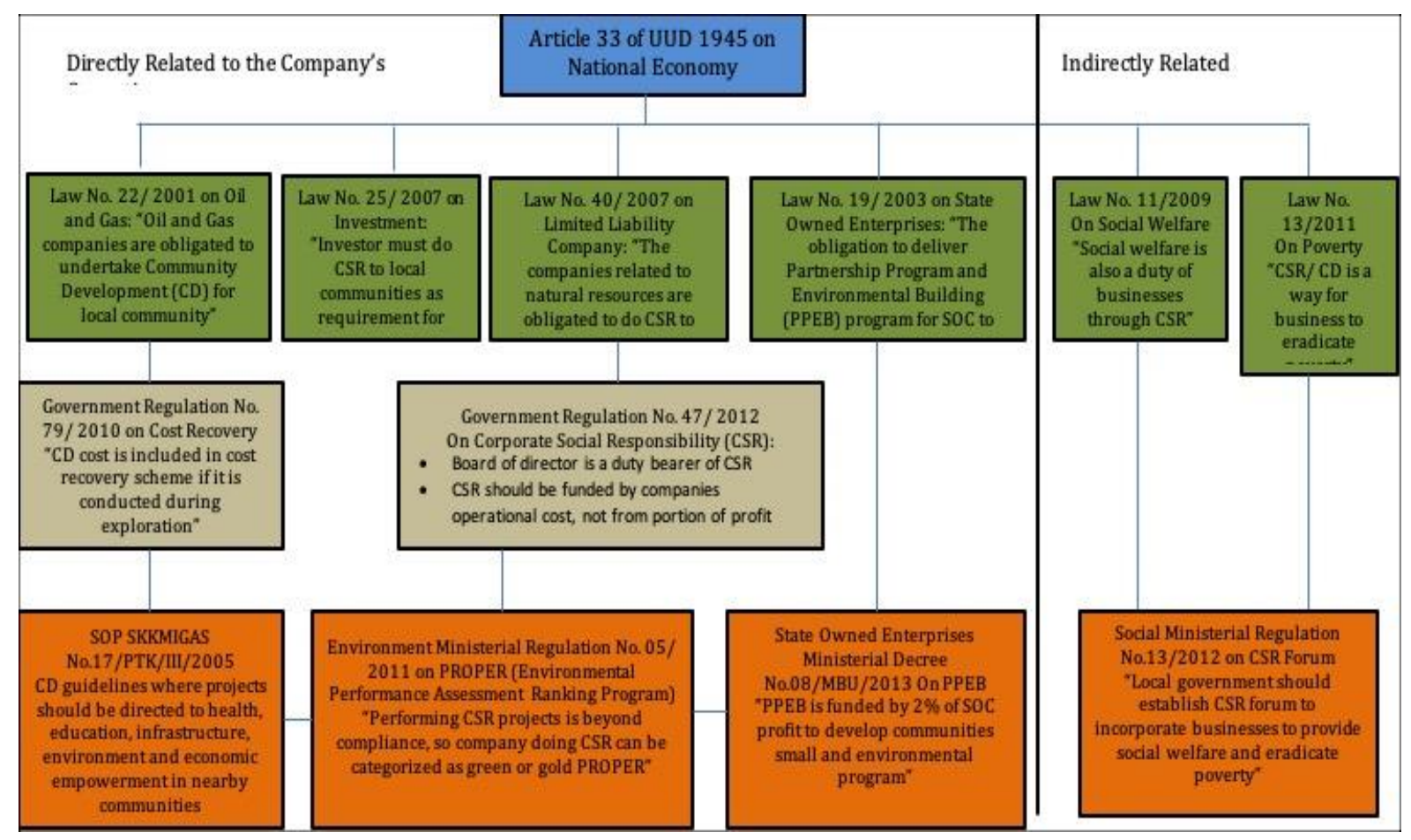

Figure 2. Indonesia CSR Legislation Framework

Only five of the six laws have implementation regulations. The Law on Oil and Gas No. 22/2001 does not have relevant regulations for how to implement Community Development in the field; instead, the direction is only provided in Government Regulation No. 79/ 2010 on Cost Recovery, confirming CD projects as part of cost recovery if the cost is expended during the exploration stage (before exploitation or production). Further CD guidelines are included in SOP No. 17/PTK/III/2005 (BPMIGAS 2005), issued by BPMIGAS (Badan Pelaksana Kegiatan Usaha Hulu Minyak dan Gas - The Regulatory Body for Oil and Gas Upstream Activities) which has changed to now be SKKMIGAS (Satuan Kerja Khusus Pelaksana Kegiatan Usaha Hulu Minya dan Gas - a special Task Force for Upstream Oil and Gas Business Activities), directing CD programs into five areas: health, education, infrastructure, environment and economic empowerment. Law No 40/2007 on Limited Liability Company has an implementation regulation via Government Regulation No. 47/ 2012 on CSR. This implementation regulation directs the board of directors in companies as the main bearer of responsibility with respect to this law; and points out that the funding should be derived from company operational costs instead of company profits. For specific State Owned Companies (SOC) the ministry has set Ministerial Decree No. 08/MBU/2013 on Partnership Program and Environmental Building (or PKBL-Program Kemitraan dan Bina Lingkungan), declaring that PPEB funds are taken from 2 percent of company profits. Under indirect Law No. 11/ 2009 on Social Welfare and Law No. 13/ 2011, the Social Minister passed Regulation No. 13/ 2012 encouraging local governments to establish CSR forums. There is also PROPER (Program Penilaian Peringkat Kinerja Perusahaan dalam Pengelolaan Lingkungan Hidup - Environmental Performance Assessment Ranking Program) regulation, a program of the National Environment Minister to rank companies' performance 
in maintaining the environment. Through the Environmental Minister's Regulation No. 5/ 2011, CSR projects conducted by companies are categorized as beyond compliance, giving consideration for the companies to be included in the green or gold categorizations of ranking.

There are four pertinent observations generated from Figure 2. Firstly, all laws and their implementation regulations have been issued after 2000, or after the decentralization process was begun. This indicates that the issuance of CSR legislation is a form of response to the local stakeholder pressures and demands on companies for contributions to local development during the decentralization era. Secondly, the legislation applies to companies' operations in natural resources. This statement on CSR legislation suggests that CSR is a consequence of the increasing claims from locals who have natural resources located in their area. CSR has been seen by central government as a tool to satisfy this claim; however, they still retain control of some natural resources, particularly oil and gas. Thirdly, CSR legislation positions local communities as the main beneficiaries of CSR projects. This means that the objective of CSR is to help local communities where the companies are operating. However, the term 'local communities' can be interpreted in various ways across different borders: it can refer to local communities in the villages, districts or provinces where company operations are located. In this manner, local district governments may direct companies to deliver their CSR to other villages outside of the companies' areas of operation given it is beneficial to local communities of the district; or the local provincial government may direct company CSR to be delivered to a district outside the company's district area, considering the welfare of the local community's province area. Fourthly, Figure 2 also highlights that no regulations issued by local government have actually been approved. Some efforts from local government had been raised to issue local regulation on CSR. However, the Ministry of Domestic Affairs eventually dismissed the regulation drafts, although the district legislative authority had approved the regulation.

The reason for these cancellations is in the main because the central government is afraid such regulation may harm the business climate in the district, and this may impact the national business situation. According to a study conducted by SMERU, an Indonesian NGO, these local CSR regulations began to treat companies' CSR as a source of donations, corrupting district chiefs and burdening the businesses involved. This provoked the central government to dissolve Perdas (local regulation), which was thus seen to have become detrimental to Indonesia's business climate (Bachtiar, 2009). Thus, while on one hand, the exercise of central government power is generally discouraged in this decentralization era, this case highlights how central government can overrule local authorities by justifying how one local regulation is not in line with the central government rules.

\subsection{The Mandate to Businesses}

The complex CSR legislative landscape raises the question of what is the intended mandate of this legislation for companies. Aside from the differentiation in terms used to describe their social responsibilities in the various laws, it is important to understand the principle mandate that should be complied with by the companies. Table 2 below is used to examine the various 


\section{$\triangle 1$ Macrothink}

Business and Economic Research

ISSN 2162-4860

2019, Vol. 9, No. 3

CSR laws and implementation regulations and decrees in order to identify similarities and/or the differences in the messages of the legislation, and thus enable us to identify the central intention of the mandate of CSR legislation.

Table 2 below shows important aspects of the six laws and their relevant regulations and decrees identified in this study, which are Law No. 22/2001 on Oil and Gas, Law No. 19/2003 on State Owned Companies, Law No. 25/2007 on Investment, Law No. 40/ 2007 on Limited Liability Company, Law No. 11/2009 on Social Welfare, and Law No. 13/2011 on Poverty. In order to find the main mandate of all these various laws, the table categorizes three aspects of the laws that can describe succinctly the content of the laws: the mandate to business; mechanism of implementation; and sanctions. Using document analysis, the six laws and their implementation regulations have been analysed to categorise them within these three aspects.

Table 2 shows the form of CSR activities and their targets stated in the six laws. Law No.22/2001 on Oil and Gas mandates Oil and Gas companies to develop the local communities and environment, whilst Law No. 19/2003 on SOC also aims for local community development by specifically targeting small community businesses as beneficiaries. Law No. 25/2007 on Investment stipulates the obligation of investors to implement CSR and respect the local traditions. Law No. 40/2007 on Limited Liability Company states that the related natural resource companies budget CSR for local communities annually. Law No 11/2009 on Social Welfare and Law No. 13/2011 on Poverty similarly mandate businesses to take on a role in social welfare and poverty eradication through CSR.

Table 2. Laws, Mandate, Mechanism of Implementation and Sanctions

\begin{tabular}{|c|c|c|c|}
\hline Law & Mandate to Businesses & $\begin{array}{l}\text { Mechanism of } \\
\text { Implementation }\end{array}$ & Sanctions \\
\hline $\begin{array}{l}\text { Law No 22/ } \\
2001-\text { Oil and } \\
\text { Gas }\end{array}$ & $\begin{array}{l}\text { - Oil and Gas Companies } \\
\text { have a responsibility to } \\
\text { develop environment and } \\
\text { local community }\end{array}$ & 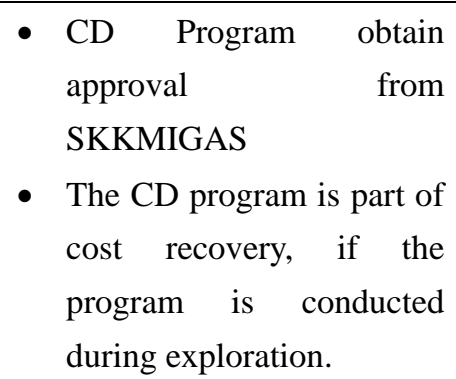 & - Not specified \\
\hline $\begin{array}{l}\text { Law No. 19/ } \\
2003-\text { State } \\
\text { Owned } \\
\text { Enterprises }\end{array}$ & $\begin{array}{l}\text { - Beneficiaries are the small } \\
\text { entrepreneur, cooperative, } \\
\text { and community } \\
\text { - Program is developed } \\
\text { under PPEB }\end{array}$ & $\begin{array}{l}\text { - Programs are managed by } \\
\text { unit under board of } \\
\text { directors } \\
\text { - Funding for PPEB is taken } \\
\text { from } 2 \text { percent of SOC net } \\
\text { profit. } \\
\text { - Program should be } \\
\text { approved by shareholders } \\
\text { (central government) }\end{array}$ & - Not Specified \\
\hline
\end{tabular}




\begin{tabular}{|c|c|c|c|}
\hline Law & Mandate to Businesses & $\begin{array}{l}\text { Mechanism } \\
\text { Implementation }\end{array}$ & Sanctions \\
\hline $\begin{array}{l}\text { Law No. 25/ } \\
2007 \\
\text { Investment }\end{array}$ & $\begin{array}{l}\text { - Every investor must } \\
\text { perform CSR and respect } \\
\text { the community cultural } \\
\text { tradition around the } \\
\text { operation }\end{array}$ & - Not specified & $\begin{array}{l}\text { - Administrative } \\
\text { sanctions (article 16). }\end{array}$ \\
\hline $\begin{array}{l}\text { Law No. 40/ } \\
\text { 2007- } \\
\text { Limited } \\
\text { Liability } \\
\text { Company }\end{array}$ & $\begin{array}{l}\text { - CSR is the obligation of } \\
\text { company conducting its } \\
\text { business related to natural } \\
\text { resources } \\
\text { - CSR must be budgeted in } \\
\text { the company's cost }\end{array}$ & $\begin{array}{l}\text { - The obligation is on board } \\
\text { of directors to make CSR } \\
\text { annual plan } \\
\text { - Annual work plan should } \\
\text { contain activities and } \\
\text { budget of CSR }\end{array}$ & $\begin{array}{l}\text { - Sanctions will be } \\
\text { given according to } \\
\text { the related laws } \\
\text { - Not specified which } \\
\text { are the related laws }\end{array}$ \\
\hline $\begin{array}{l}\text { Law No. } \\
\text { 11/2009 - Social } \\
\text { Welfare }\end{array}$ & $\begin{array}{l}\text { - Role of business in social } \\
\text { welfare is in their CSR } \\
\text { - CSR funds for social } \\
\text { welfare are a form of } \\
\text { business obligation to their } \\
\text { social and environment }\end{array}$ & $\begin{array}{l}\text { - CSR forum should be } \\
\text { established at national and } \\
\text { provincial levels to } \\
\text { integrate all businesses in } \\
\text { CSR }\end{array}$ & - Not specified \\
\hline $\begin{array}{l}\text { Law No. 13/ } \\
2011 \text { - Poverty }\end{array}$ & $\begin{array}{l}\text { Business role in alleviating } \\
\text { poverty is to provide funds } \\
\text { in form of CSR to the poor }\end{array}$ & - Not specified & - Not specified \\
\hline
\end{tabular}

It is evident from the six laws that the intended beneficiaries of CSR are local communities and their environment. However, the definition of 'local communities' is not specified in those laws, whether it is directed to the community in the village, sub district, district, or provincial level. For instance, the provincial government can demand CSR projects from a company to build infrastructure, by claiming it is for the people in the province. The specific mandate of social duty to local communities and their environment is presented only in Law No. 19/2003 on SOC and their implementation regulations aimed at small and medium sized enterprises (SMEs), koperasi (cooperative) organizations and local community businesses. Furthermore, the social duty of businesses is made very broad in Social Welfare Law No. 11/ 2009 and Poverty Law No. 3/ 2011, by positioning businesses in their CSR to contribute to improving social welfare and poverty eradication. The other laws and their implementation regulations are not clear in defining what kind of CSR should be conducted by companies. This means that the CSR activities that are undertaken by companies may vary, so that contributing to a charity in the local communities by giving a cow for celebrating 'sedekah kampung'(a village celebration) is considered as CSR, although this donation is not strictly in line with the goal of CSR laws to develop local communities.

Another issue arising with this theme is the clear obligation for companies to spend their money or resources for CSR activities. CSR projects in Law No. 40/2007 on Limited Liability Company and Law No. 25/2007 on Investment are derived from the annual budget 
of companies' operational cost. PPEB projects in Law No 19/2003 on State Owned Companies are financed by two percent of a company's net profit. CD projects in Law No 22/2001 on Oil and Gas are funded by companies or by cost sharing with the government if the projects are under the exploration stage. The focus of CSR laws on the distribution of funds in CSR explicitly shows that the role of businesses in CSR is actually to provide funds or wealth to local communities. Apart from the businesses' contribution in their investment to the country, job creation and tax revenue to the government, the businesses' CSR is assumed as part of companies' contributions to local communities. This implies that the main mandate of CSR in the six laws and their implementation regulations is essentially to distribute a share of companies' wealth to local communities.

The legal sanctions that apply to companies who fail to implement CSR programs are rather ambiguous in the CSR legislation. Table 2 above indicates only two laws stating legal sanctions. Law No. 25/2007 on Investment sets out administrative sanctions in the form of written warning from central government, limitation of business activities, freezing of investment activities or the revocation of investment permits. However, these sanctions apply to investors who fail to comply with all requirements stated in the Law of Investment, including CSR activities. This means that the sanctions are not specifically set to punish businesses that are not conducting CSR. The Law No. 40/2007 on Limited Liability Company also provides sanctions for companies that are not conducting CSR. However, the sanctions are not detailed, but only state that 'sanctions will be given in accordance with related laws'. This statement is ambiguous, as the law provides no further explanation and no other CSR legislation refers to sanctions for non- compliance.

Given this finding, whilst symbolically the CSR legislation seems to apply a hard approach, in practice the Indonesian CSR legislation is not as severe as it looks. The hard CSR rules discussed in Chapter 3 apply to the government approach to CSR in forcing companies to conduct CSR through giving penalties or punishments to the companies if they do not perform CSR. In the case of Indonesia's CSR laws, it is evident that the government issued the laws to rule companies regarding CSR. However, the lack of sanctions through clear penalties in the legislation weakens the enforcement of these laws. In addition, the weak law enforcement culture in Indonesia may contribute to the lack of implementation of these CSR laws, impeding the goal of the laws to improve the lives of local people, and bringing into question how serious the central government is about this goal.

\section{Conclusion: CSR as Wealth Distribution}

The literature on CSR in developing countries has suggested that businesses should be involved in developmental issues in these countries, such as providing health and education infrastructure, addressing poverty and even human rights issues (Blowfield \& Frynas, 2005; Idemudia, 2011). However, the literature largely views that the involvement of CSR in those issues through the lens of voluntary CSR, depending on companies self-initiative (Desta, 2010; Dobers \& Halme, 2009). The adoption of mandated CSR legislation by the Indonesian central government provides an alternative way for developing countries to engage businesses in social provision. This is important in a country whose development challenges 
are great and whose government capacity to deliver is limited. It also provides an opportunity to leverage and learn from the expertise of MNCs.

Moreover, the question arises as to what exactly should be mandated for CSR, as an important area for discussion. In the context of Indonesia, the phenomenon of mandating CSR as wealth distribution cannot be detached from the context of the decentralization process occurring in Indonesia since 1999. Since decentralization, the central government in Jakarta has issued new tax and fiscal balance policies as instruments to distribute funds to local government (Agustina, Ahmad, Nugroho, \& Siagian, 2012). A proportion of tax revenue collected by the central government is now shared with local government annually through the Dana Alokasi Umum (General Allocation Fund) and Dana Alokasi Khusus (Special Allocation Fund). Local governments have also received the authority to collect small taxes in the form of restaurant and hotel taxes and parking retributions, and include these in their local budget as Pendapatan Asli Daerah (Local Revenues). Dana Bagi Hasil, or the revenue sharing policy from the mining sector, is also one instrument of central government to fulfil local district requests for more contributions from the mining operations in their regions. These contributions have been partly transferred from the central government to local government through Dana Bagi Hasil (Revenue Sharing Fund).

However, the local district government felt that this fund was still not sufficient for their local development (Budiartie, 2012). The disparity in infrastructure conditions between Jakarta and less developed local districts requires enormous funding to redress. The local governments perceive that the present fiscal balance policy is 'unfair' due to the insufficient funding received by local government. Therefore, the revenue sharing fund from central government seems insufficient. In addition, the local district stakeholders believe that this portion is not equal to the environmental and social impacts that the district receives from the mining industry.

The voluntary CSR applied in developed western countries prefers taxation as a tool of wealth distribution; however, this approach makes the assumption that the taxation system is the capacity to enforce, both of which may not be the case in Indonesia. This might be a reason why CSR has been to utilised by Indonesian central government as a policy instrument for wealth distribution to local regions. In fact, rather than increasing the proportion of revenue sharing from Oil and Gas production to local districts, the central government has preferred to utilise companies' CSR resources to fulfil local demands. Therefore, mandating CSR in the form of company funding allocations for local development has been an alternative source of funding for central government to address local complaints about inadequate funding distribution to them. Moreover, the increase of local protests over the impacts of mining operations has led the view that this company wealth distribution is necessary as compensation for what they have done to the local communities.

\section{References}

Adeyeye, A. (2011). Universal standards in CSR: are we prepared?. Corporate Governance: The International Journal of Business in Society, 11(1), 107-119.

https://doi.org/10.1108/14720701111108880 
Adeyeye, A. O. (2012). Corporate social responsibility of multinational corporations in developing countries: Perspectives on anti-corruption. Cambridge University Press. https://doi.org/10.1017/CBO9781139005067

Agustina, C. D., Ahmad, E., Nugroho, D., \& Siagian, H. (2012). Political economy of natural resource revenue sharing in Indonesia. Presented at the paper presented to Alternative Visions for Decentralization in Indonesia, Jakarta.

Ali, W., Frynas, J. G., \& Mahmood, Z. (2017). Determinants of corporate social responsibility (CSR) disclosure in developed and developing countries: A literature review. Corporate Social Responsibility and Environmental Management.

https://doi.org/10.1002/csr.1410

Bachtiar, P. (2009). Regional Levy Collection as a Barrier to Investment. Regional Regulations and Their Impact on Business Climate.

Bakan, J. (2012). The corporation: The pathological pursuit of profit and power. UK: Hachette.

Blowfield, M., \& Frynas, J. G. (2005). Editorial Setting new agendas: critical perspectives on Corporate Social Responsibility in the developing world. International Affairs, 81(3), 499-513. https://doi.org/10.1111/j.1468-2346.2005.00465.x

Bowen, G. A. (2009). Document analysis as a qualitative research method. Qualitative Research Journal, 9(2), 27-40. https://doi.org/10.3316/QRJ0902027

Brammer, S., Jackson, G., \& Matten, D. (2012). Corporate social responsibility and institutional theory: New perspectives on private governance. Socio-Economic Review, 10(1), 3-28. https://doi.org/10.1093/ser/mwr030

Budiartie, G. (2012, February 9). Pemerintah Daerah Minta Tambah Bagi Hasil Migas (Local governments ask for mote oil and gas revenue sharing). Tempo.

Buhmann, K. (2006). Corporate social responsibility: what role for law? Some aspects of law and CSR. Corporate Governance: The International Journal of Business in Society, 6(2), 188-202. https://doi.org/10.1108/14720700610655187

Carroll, A. B. (1991). The pyramid of corporate social responsibility: Toward the moral management of organizational stakeholders. Business Horizons, 34(4), 39-48.

https://doi.org/10.1016/0007-6813(91)90005-G

Carroll, A. B. (1999). Corporate social responsibility: Evolution of a definitional construct. Business \& Society, 38(3), 268-295. https://doi.org/10.1177/000765039903800303

Delbard, O. (2008). CSR legislation in France and the European regulatory paradox: An analysis of EU CSR policy and sustainability reporting practice. Corporate Governance: The International Journal of Business in Society, 8(4), 397-405.

https://doi.org/10.1108/14720700810899149

Desta, I. H. (2010). CSR in developing countries. Responsible Business: How to Manage a 
CSR Strategy Successfully, 265. https://doi.org/10.1002/9781119206156.ch18

Dobers, P., \& Halme, M. (2009). Corporate social responsibility and developing countries. Corporate Social Responsibility and Environmental Management, 16(5), 237-249. https://doi.org/10.1002/csr.212

Donaldson, T., \& Dunfee, T. W. (1999). Ties that bind: A social contracts approach to business ethics.

Friedman, M. (2007). The social responsibility of business is to increase its profits. In Corporate ethics and corporate governance (pp. 173-178). Springer.

https://doi.org/10.1007/978-3-540-70818-6_14

Gjølberg, M. (2011). Explaining regulatory preferences: CSR, soft law, or hard law? Insights from a survey of Nordic pioneers in CSR. Business and Politics, 13(2), 1-31.

https://doi.org/10.2202/1469-3569.1351

Heidenreich, S., \& Puck, J. F. (2012). The illusion of political power: Evidence from a failed FDI in a developing market. In New Policy Challenges for European Multinationals (pp. 203-229). Emerald Group Publishing Limited.

https://doi.org/10.1108/S1745-8862(2012)0000007012

Hillman, A. J., \& Wan, W. P. (2005). The determinants of MNE subsidiaries' political strategies: Evidence of institutional duality. Journal of International Business Studies, 36(3), 322-340. https://doi.org/10.1057/palgrave.jibs. 8400137

Idemudia, U. (2008). Conceptualising the CSR and development debate. The Journal of Corporate Citizenship, 29, 91. https://doi.org/10.9774/GLEAF.4700.2008.sp.00011

Idemudia, U. (2011). Corporate social responsibility and developing countries: Moving the critical CSR research agenda in Africa forward. Progress in Development Studies, 11(1), 1-18. https://doi.org/10.1177/146499341001100101

Jamali, D., \& Mirshak, R. (2007). Corporate social responsibility (CSR): Theory and practice in a developing country context. Journal of Business Ethics, 72(3), 243-262.

https://doi.org/10.1007/s10551-006-9168-4

Krippendorff, K. (2012). Content analysis: An introduction to its methodology. Sage.

Maas, K., \& Liket, K. (2011). Talk the walk: Measuring the impact of strategic philanthropy. Journal of Business Ethics, 100(3), 445-464. https://doi.org/10.1007/s10551-010-0690-z

Matten, D., Crane, A., \& Chapple, W. (2003). Behind the mask: Revealing the true face of corporate citizenship. Journal of Business Ethics, 45(1-2), 109-120.

https://doi.org/10.1023/A:1024128730308

Porter, M. E., \& Linde, C. van der. (1999). Green and competitive: Ending the stalemate. Journal of Business Administration and Policy Analysis, 215.

Rosser, A., \& Edwin, D. (2010). The politics of corporate social responsibility in Indonesia. 
The Pacific Review, 23(1), 1-22. https://doi.org/10.1080/09512740903398314

Schwartz, M. S., \& Carroll, A. B. (2003). Corporate social responsibility: A three-domain approach. Business Ethics Quarterly, 13(4), 503-530. https://doi.org/10.5840/beq200313435

Schwartz, M. S., \& Saiia, D. (2012). Should firms go "beyond profits"? Milton Friedman versus broad CSR. Business and Society Review, 117(1), 1-31.

https://doi.org/10.1111/j.1467-8594.2011.00397.x

Vaismoradi, M., Jones, J., Turunen, H., \& Snelgrove, S. (2016). Theme development in qualitative content analysis and thematic analysis. Journal of Nursing Education and Practice, 6(5), 100. https://doi.org/10.5430/jnep.v6n5p100

Van Marrewijk, M. (2003). Concepts and definitions of CSR and corporate sustainability: Between agency and communion. Journal of Business Ethics, 44(2-3), 95-105.

https://doi.org/10.1023/A:1023331212247

Waagstein, P. R. (2011). The mandatory corporate social responsibility in Indonesia: Problems and implications. Journal of Business Ethics, 98(3), 455-466.

https://doi.org/10.1007/s10551-010-0587-X

Windsor, D. (2006). Corporate social responsibility: Three key approaches. Journal of Management Studies, 43(1), 93-114. https://doi.org/10.1111/j.1467-6486.2006.00584.x

Zainal, R. I. (2006). Best practices: Corporate social responsibility (CSR): sebuah pengalaman membangun multistakeholder engagement bagi penerapan CSR di Kabupaten Muba, Sumatera Selatan. Badan Penerbit Fakultas Ekonomi Unsri supported by Partnership for Governance Reform in Indonesia, European Union, and UNDP.

\section{Copyright Disclaimer}

Copyright for this article is retained by the author(s), with first publication rights granted to the journal.

This is an open-access article distributed under the terms and conditions of the Creative Commons Attribution license (http://creativecommons.org/licenses/by/3.0/). 